\title{
Experience of the rapid implementation of a pioneering telehealth service during the COVID-19 crisis
}

\author{
Experiência da rápida implementação de serviço pioneiro em telessaúde durante a crise da Covid-19 \\ Brunnella Alcantara Chagas de Freitas' 10 |brunnella.freitas@ufv.br \\ Wilmara Lopes Fialho' (1) wilmara.fialho@ufv.br \\ Mara Rubia Maciel Cardoso do Prado' (1) mara.prado@ufv.br
}

\begin{abstract}
Introduction: Based on a national ordinance that regulates and operationalizes telemedicine as one of the measures to cope with the public health emergency resulting from the COVID-19 epidemic, a partnership was established between the federal university and municipal management for the rapid implementation of the telehealth service for COVID-19.

Experience report: Experience report on the implementation process of the specific telehealth service for COVID-19, a partnership between the academy and the service.

Discussion: The implementation process requires team sizing, physical space and technological resources, training and continuous education of the team to align the actions, for the agreement and articulation of the call center and telemonitoring flowchart with the local health network at all levels of care, disclosure of the service to the population, attention to ethical aspects, criteria for issuing documents, standing out and integration of the team regarding the clinical approach in teleconsultation and telemonitoring.

Conclusion: The experience of implementing the Telehealth Covid service in 27 days is reported in this article, and it is likely to be replicated by other municipalities, as a contingency measure due to COVID-19. The significant number of visits, the social mission of the public university and its articulation with the local health system stand out after two months of operation.
\end{abstract}

Keywords: COVID-19; Telemedicine; Telehealth; Public Health; Coronavirus infections.

\section{RESUMO}

Introdução: Com base em portaria nacional que regulamenta e operacionaliza a telemedicina como uma das medidas de enfrentamento da emergência de saúde pública decorrente da epidemia de Covid-19, firmou-se uma parceria entre a universidade federal e a gestão municipal para a rápida implementação do serviço de telessaúde para Covid-19.

Relato de Experiência: Trata-se de relato de experiência do processo de implementação do serviço de telessaúde específico para Covid-19, uma parceria entre academia e serviço.

Discussão: $O$ processo de implementação requer dimensionamento da equipe, espaço físico e recursos tecnológicos, treinamento e capacitação contínua da equipe para alinhamento das ações, pactuação e articulação do fluxograma de teleatendimento e telemonitoramento com a rede de saúde local em todos os níveis de atenção, divulgação do serviço para a população, atenção a aspectos éticos e critérios de emissão de documentos, com destaque à apropriação da equipe quanto à abordagem clínica na teleconsulta e no telemonitoramento.

Conclusão: A experiência de implementação do serviço Telessaúde Covid em 27 dias relatada neste artigo é passível de replicação por outros municípios como medida de contingenciamento da Covid-19. No relato, destacam-se o número expressivo de atendimentos após dois meses de funcionamento, a missão social da universidade pública e a articulação dela com o sistema de saúde local.

Palavras-chave: Covid-19; Telemedicina; Telessaúde; Saúde Pública; Infecções por Coronavírus.

${ }^{1}$ Universidade Federal de Viçosa, Viçosa, Minas Gerais, Brazil.

Chief Editor: Daniela Chiesa

Associate Editor: Rosiane Viana Zuza Diniz

Received on 06/29/20; Accepted on 01/18/21.

Evaluated by the double blind review. 


\section{INTRODUCTION}

Faced with the global health scenario of COVID-19 since February 2020, representatives of Universidade Federal de Viçosa (UFV), the Municipality of Viçosa-MG (PMV, Prefeitura Municipal de Viçosa-MG), health care services and several sectors of the municipality came together to establish contingency strategies for COVID-19 in the region.

Viçosa is a Brazilian municipality in the interior of Minas Gerais, Southeast region of the country, located in the Zona da Mata region, with an estimated population of 78,846 inhabitants in 2019 and its health region comprises 10 municipalities. Universidade Federal de Viçosa (UFV) is a public institution, of which headquarter is located in Viçosa.

On March 20, 2020, the Ministry of Health published Ordinance N. 467, related on an exceptional and temporary basis to actions in Telemedicine, aiming at regulating and operationalizing measures to deal with the public health emergency of international importance due to the COVID-19 epidemic. This Ordinance authorizes, on an exceptional and temporary basis, telemedicine actions, remote interaction, which may include pre-clinical care, assistance support, consultations, monitoring and diagnosis, carried out through information and communication technology, within the scope of the Brazilian Unified Health System (SUS, Sistema Único de Saúde) $)^{1-3}$.

Therefore, one of the strategies, through a partnership between the Department of Medicine and Nursing at UFV (DEM, Departamento de Medicina e Enfermagem/UFV) and the Municipal Health Secretariat (SMS, Secretaria Municipal de Saúde), was the implementation of the telemedicine service called "Telessaúde Covid" (Telehealth Covid). On March 17, 2020, the municipality implemented a telehealth service for COVID-19 and, on March 27, the partnership between UFV and PMV was signed for its expansion and restructuring. The process took place on April 22, 2020, under the name "Telessaúde Covid".

Telehealth Covid aims to provide qualified remote assistance, through technologies, to people with symptoms suggestive of COVID-19, with doubts or a history of contact with a confirmed or suspected case of the disease. In the COVID-19 scenario, the service plays a fundamental role in preventing unnecessary patient displacement, reducing the burden on health services and the spread of the virus within the community through adequate guidance, whether for home monitoring or for face-to-face evaluation at the appropriate health unit, following the local contingency plan ${ }^{1-4}$.

\section{EXPERIENCE REPORT}

The process for implementing the Telehealth Covid Team sizing

Initially, among the network professionals involved in the Municipal Health Secretariat (SMS) service, there were the multiprofessional teams from the Family Health Support Center (NASF, Núcleo de Apoio à Saúde da Família) and the Multiprofessional Home Care Team (EMAD, Equipe Multiprofissional de Atenção Domiciliar).

The expanded service now consists of 16 interns with scholarships from the SMS (08 students attending the last two years of medical school and 08 students attending the last year of the nursing school, all from UFV), health professionals from NASF, professors / preceptors from DEM, nurses and doctors from DEM, and also resident doctors and veterinarians from UFV's Medical Residency and Veterinary Medicine Programs. There is always a supervising doctor and nurse on duty.

Telehealth Covid operates for 12 hours a day, every day of the week. The team's functions are distributed as follows: (a) five assistants who are directly responsible for the call center and telemonitoring service, with four interns from the medical and nursing courses and one NASF/SMS professional; (b) two supervisors, a doctor and a nurse from DEM/UFV, who are teachers, higher education technicians or resident doctors from the Medical Residency Program; (c) a regulator, a veterinary doctor from the Veterinary Medicine Residency Program at UFV. There are 6-hour or 12-hour shifts, depending on the professional's employment link with the institution.

\section{Physical space and technological resources}

The Telehealth is in operation at the DEM/UFV Informatics Laboratory, under supervision from the Information Technology Directory, with the possibility of expansion. There are enough computers, extensions have been added, headsets and extensions have been purchased for the supervisor to follow the teleconsultation if necessary, and the acquisition of tablets and WhatsApp is scheduled to assist in the clinical evaluation ${ }^{2,4,5}$.

Telehealth Covid carries out consultations by telephone. The video consultation is being implemented and will be carried out by WhatsApp, when the attendant and supervisor deem it necessary, and if the patient has the technological resources to do so. The Telehealth Covid WhatsApp account will be used exclusively for video consultations, and will be blocked for incoming calls and messages, being only able to make video calls or send and receive documents when the team considers it necessary (such as prescriptions issued by the service, receiving images of patients' prescriptions, among other situations). Through the WhatsApp Business function, one can configure absence and greeting messages, automatic 
responses, educational messages and offer guidance in an objective manner, in addition to being able to separate patients by categories, for instance, all those who will be monitored every 24 are marked in red ${ }^{2,4,5}$.

An e-mail of the service was created to issue and receive documents and to communicate with other health sectors and with the Epidemiological Surveillance Service.

\section{Continuous training and qualification of the team to align actions}

The initial training of the entire team was carried out by videoconference and complemented by the in-person support of the coordination team in some shifts at the beginning of the service. The use of attending techniques similar to the faceto-face ones was prioritized, adopting the Patient-Centered Clinical Method for the clinical interview ${ }^{5,6}$.

The initial training aimed at COVID-19 prevention measures inside the organization itself was carried out together with the DEM/UFV professionals involved in the topic.

Continuous training of the team related to updates issued by scientific entities has been maintained.

A manual for the Telehealth Covid service was created by the coordination team, in line with the SMS, and with the support of the Institutional Communication Directory of UFV regarding its layout and online dissemination on the institution website. The manual aims at aligning the Telehealth actions between the team and the several health sectors, thus designing the flow of patient care within the health network ${ }^{2,7-9}$.

\section{Agreement and articulation of the teleconsultation and telemonitoring flowchart with the local health network at all levels of care}

The actions follow the PDCA cycle: Plan, Do, Check and Act. The meetings between the Telehealth Covid coordination and health management representatives take place weekly, as well as the coordination dialogue with the service team.

Therefore, a flowchart was agreed on, which articulates the Telehealth Covid actions with the different health sectors and, also, semi-structured forms were created for the call center and the telemonitoring sectors. Everything was created and reassessed continuously, based on documents from the Ministry of Health, State Health Secretariats and scientific institution protocols, with adaptation and articulation to the local health network, at all levels of care, and in accordance with the agreements between SMS and UFV 2,4,8,10-15.

\section{Disclosure of Telehealth Covid to the population}

The Telehealth Covid service has been widely disclosed in different media, giving advice on what kind of the situations the population should call the service. Moreover, there is a dialogue between the communication sectors of PMV and UFV for the dissemination of information in a coherent way.

\section{Ethical aspects and document issuance}

In every consultation, patients are asked whether they authorize it to be carried out by telephone. The attendant must properly identify the patient and also identify themselves to them, explaining, in the case of an intern, that the patient will be followed by medical supervisors and nurses. All obtained information must be explained and shared with the patient, and the attendant must check whether they have been well understood. The consultation must be recorded on the care and monitoring sheets, which are the medical records and, if the team considers it necessary to add additional information, these are recorded on the Problem Oriented Record (POR) model, which contains the patient's identification data ${ }^{5,16}$.

If it is necessary to prescribe medication, always check for drug allergies, kidney function and the patient's previous health problems, in addition to advising on possible allergies and side effects, while recording this information in the question and advice file $e^{5,16}$.

When sending necessary documents to the patient, they can only be sent to the person's own WhatsApp or email account, email of another health institution (to be accessed by a doctor or nurse) or another health professional (doctor or nurse), as they are patient documents and confidentiality must be maintained. As a priority, these documents must contain a digital signature and be in PDF format, for security reasons ${ }^{17}$.

If the patient is instructed to stay in self-isolation at home, and requires a certificate for themselves or any member of the household or needs a prescription for Oseltamivir, provide advice on self-isolation and observation of allergic or side effects of the medication ${ }^{2,9,18,19}$.

The Term of Responsibility for home isolation and Declaration of home contacts must have its importance and implications duly explained by the attendant, as well as the procedure, so the patients can give their consent. Instruct the patient about the procedure adopted by the team for issuing documents (certificates or prescriptions), reinforcing that they will be sent after receiving the Term of Responsibility for home isolation and Declaration of home contacts duly completed and consented by the patient via an online form ${ }^{2,9,18-20}$.

The clinical approach in teleconsultation and telemonitoring

The teleconsultation has some characteristics regarding clinical communication and physical examination, and because it is carried out through technological means of communication, 
it must be prevented from looking like a "telemarketing service" and, therefore, an impersonal checklist ${ }^{5}$.

Initially, it is necessary to establish the reason for the telephone contact, whether teleguidance or teleconsultation and, if it is a teleconsultation, it is necessary to investigate severity criteria for the early adoption of relevant procedures. The following red flag symptoms indicate that the patient needs urgent evaluation (either in person or by video, depending on the clinical circumstances): severe shortness of breath or difficulty breathing, pain or pressure on the chest, blue lips or face and a history suggestive of shock (such as cold, damp skin, mental confusion, drowsiness or significant reduction in urine production) ${ }^{5}$.

The consultation must follow a logic similar to that of face-to-face care, preferably adopting the Patient-Centered Clinical Method (PCCM) for the clinical interview (6). The following are some communication suggestions ${ }^{5,6}$.

The intern, professional or supervisor answers the phone, in their turn, and says "Telehealth Covid, name of the attendant, good morning / good afternoon / good evening, how can I help you?". After that, check with whom you are talking, always try to talk to the patient, unless there is any impediment to that (age, severity, hearing impairment); request the patient's consent for the assistance/guidance to take place by phone; remember that the form is only a guide, avoid using it as a checklist, and only ask questions that are appropriate as to why the person is calling; ask open-ended questions initially, avoiding inducing the patient, such as "What else?", "Tell me more about it", "What do you mean by shortness of breath? Tell me more"; use tools such as 'mute' (taking care so that the patient will not think the connection has dropped), echo and paraphrase; address feelings, ideas, function and expectations (FIFE method) when necessary (e.g. patient insists on being tested for COVID, without indication) $)^{5,6}$.

Expectations are often a source of distress for people at this moment of a pandemic, as many individuals call, for instance, because they are apprehensive, for fear of being sick and transmitting to their loved ones, while others expect to be tested or think the teleconsultation professionals will go to their homes to perform an evaluation ${ }^{6}$.

Ask the targeted questions you consider to be necessary: "How old are you?", "Are you coughing? Do you have a sore throat? Fever?" (if yes, "What is your temperature?"), "How is your breathing? Do you have shortness of breath?", "When did all this start?", "Do you have smell and taste alterations?". Be careful not to induce patients in their answers, not all of these questions always need to be asked, since the patient said, for instance, that they do not have a temperature ${ }^{5,6}$.

If the patient deviates from the consultation subject to something inappropriate, you can demonstrate that you understand what they are displaying and then ask them to return to what you were talking about.

Check for previous comorbidities, also in an open manner, such as in the following example: "Do you have any health problems?". If the patient denies it, ask: "Do you use any medications?" If the patient replies that they use an antihypertensive drug, for instance, you can ask: "What do you use this medication for?". If they do not know: "Have you ever been told that you have high blood pressure?"5,6.

Summarize to the patient what you have understood from what they told you and ask them to check if nothing is missing. Always check whether the patient has had contact with a confirmed or suspected case of COVID-192,5,6.

If the patient has a thermometer or device to measure blood pressure, they can be asked to check them and inform these data at the time of the call. The assessment of shortness of breath can be performed by open-ended questions as follows: "How is your breathing?", "What makes you get tired?", "Are you so tired that you cannot speak more than a few words?", "Are you breathing harder or faster than normal when you are resting?", "Are you so sick that you stopped doing all your usual daily activities?", "Are you breathing faster, slower or equal to normal?", "What makes you feel breathless?"5,6.

If there is any physical examination data that the team wants to assess by video consultation, such as, for instance, the respiratory rate or the technique used by the patient to measure blood pressure, this can be done using the tablet device with WhatsApp available next to the computer ${ }^{4,5}$. In this case, one should again check whether the patient authorizes the video call and if they know how to use the tool, or if there is someone at home they would authorize to help them and accompany them during the consultation. Reintroduce yourself to the patient, make sure they can see and hear you properly, and perform the consultation. If the connection is bad, or if the patient does not know how to use the tool, or does not have someone to help them, and the team considers it necessary to check the physical examination, refer the patient to in-person care ${ }^{2,5,6,15}$.

If you need to see any of the patient's examination or prescription, you can ask them to send it by email or WhatsApp, while remembering to identify yourself and communicate in a formal, clear and objective way. If Oseltamivir is indicated, check kidney function (if there are comorbidities that can affect it, drug allergy and weight) $2,5,18$.

If the patient is instructed to stay in self-isolation at home, needs a certificate for themselves or someone in the household, or has an indication for Oseltamivir, provide advice on selfisolation and the observation of allergy or side effects of the medication. Moreover, advise them on the procedure adopted by the team for signing the document and receiving the files, reinforcing that they will be sent after the form is completed ${ }^{2,4,5}$. 
Make room for the patient's doubts, address their feelings and, if necessary, use the NURS tool: Naming; Understanding; Respecting; Supporting. For instance: "I notice that you are crying", remain in silence for some time ${ }^{21}$.

Clarify the patient's doubts, if any. Ask the patient to repeat what they understood from what was said. If any information is missing, clarify and ask the patient to repeat. Say goodbye cordially and tell them the service is available, and that in case of worsening, new symptoms or doubts, the patient should call. Give the advice clearly and objectively and inform about the monitoring that will be carried out, if that is indicated ${ }^{5,6}$.

In the end, fill out the identification header. Avoid doing this in the beginning, so as not to compromise communication. Proceed to record the consultation and, if it is necessary to record the evolution, do it according to the $\mathrm{POR}^{5,16}$.

In cases of telemonitoring, the same logic must be followed, with adequate identification of who is making the call, informing that the monitoring is being carried out, and patient compliance must be obtained. After the initial presentation, ask, in an open manner, how the person has been since the last contact with the team and remember that the consultation form is just a guide. If the patient says that they are well, without any symptoms, avoid asking details about each of the points contained in the form; however, questions such as maintenance of self-isolation or symptoms in home contacts should always be asked $2,4,12,20$.

\section{Budget}

The costs related to human resources were funded by SMS (scholarships for interns, NASF professionals) and UFV (doctors, nurses and veterinarians). The costs related to permanent material, personal protective and hygiene equipment, as well as the physical space, were paid by UFV.

Table 1 shows the costs of permanent material for Telehealth Covid operation. The cost of personal protective and hygiene equipment must also be accounted for in the development of activities: surgical masks, 70\% liquid alcohol for surface cleaning, $70 \%$ alcohol gel for hand hygiene.

\section{Initial experience}

In thecurrent context, the number of confirmed cases/deaths in Brazil, Minas Gerais and Viçosa is 1,145,906/52,645, 29,897/720 and 52/0, respectively. The first confirmed case of COVID-19 in the municipality dated of April 23, 2020. As of June 23, 2020, of the 1,651 cases notified in the municipality, $61.8 \%(n=1021)$ were tested, totaling 52 confirmed cases. After two months of operation, Telehealth performed: 715 new consultations; 417 notifications, comprising $25.3 \%$ of the total notifications of the municipality; and a total of 3,632 consultations, considering incoming calls and calls made for telemonitoring.

The service follows the principles of face-to-face service, preferentially adopting the Patient-Centered Clinical Method for the clinical interview. According to the service experience, the mean time spent at the first consultation is 30 minutes and, for monitoring, 15 minutes.

Active and continuous surveillance of patients in selfisolation at home is essential, maintaining the communication between the health professional and the patient during all domestic care up to the end of the isolation period, reviewing symptoms and the evolution of the condition. When the need for in-person assessment of the patient is identified, Telehealth Covid schedules the appointment at the referral Health Unit and, when a severe situation is identified, an ambulance is sent and the patient is transferred to the referral hospital $(2,4,5,15)$.

In view of the current knowledge, telemedicine should no longer be considered an option or complement for the health care system when reacting to an emergency; however, it is necessary to continue performing studies to validate and overcome obstacles to its use ${ }^{15,22,23}$.

\section{CONCLUSIONS}

The experience of implementing Telehealth Covid service in 27 days is reported in this article, which is likely to be replicated by other municipalities, as a COVID-19 contingency measure. It is noteworthy the significant number of consultations after two months of operation, the social mission of the public university and its articulation with the local health system.

Table 1. Costs with permanent material for Telehealth operation

\begin{tabular}{lccc}
\hline \multicolumn{1}{c}{ Item } & Quantity & Unit value (in R\$) & Total value \\
\hline Computer (Desktop-Advanced model) & 10 & $7,282.00$ & $72,820.00$ \\
Tablet, Phone and WhatsApp (accepts a 3G card) & 2 & 560.00 & $1,120.00$ \\
Corded phone devices & 10 & 39.90 & 399.00 \\
Headsets & 10 & 99.00 & 990.00 \\
Total for permanent material & --- & $7,980.90$ & $75,329.00$ \\
\hline
\end{tabular}

Elaborated by the authors. 


\section{AUTHORS' CONTRIBUTION}

All authors equally participated in data collection and analysis, writing and review of the manuscript.

\section{CONFLICTS OF INTEREST}

The authors declare no conflicts of interest.

\section{SOURCES OF FUNDING}

The authors declare no sources of funding for this study.

\section{REFERENCES}

1. Brasil. Portaria no 467, de 20 de março de 2020. Dispõe, em caráter excepcional e temporário, sobre as ações de Telemedicina, com o objetivo de regulamentar e operacionalizar as medidas de enfrentamento da emergência de saúde pública de importância internacional previstas no art. $3^{\circ}$ da Lei $n^{\circ} 13.979$, de 6 de fevereiro de 2020, decorrente da pandemia de COVID-19 [access in 7 may 2020]. Available from: http://www.planalto.gov. br/CCIVIL_03/Portaria/PRT/Portaria\%20n\%C2\%BA\%20467-20-ms.htm.

2. Brasil. Protocolo de manejo clínico do coronavírus (Covid-19) na atenção primária à saúde. Versão 9. Brasília: Secretaria de Atenção Primária à Saúde; 2020 [access in 7 may 2020]. Available from: https://www.unasus. gov.br/especial/covid19/pdf/37.

3. Bashshur RL, Shannon GW, Krupinski EA, Grigsby J, Kvedar JC, Weinstein $\mathrm{RS}$, et al. National telemedicine initiatives: essential to healthcare reform. Telemed J E Health. 2009;15:600-10.

4. Hollander JE, Carr BG. Virtually perfect? Telemedicine for covid-19. N Engl J Med. 2020;382:1679-81. doi: 10.1056/NEJMp2003539.

5. Greenhalgh T, Koh GCH, Car J. Covid-19: a remote assessment in primary care. BMJ. 2020 Mar 25;368:m1182 [access in 7 may 2020]. Available from: http://www.bmj.com/content/368/bmj.m1182.abstract.

6. Stewart M, Brown JB, McWhinney IR, Weston WW, McWilliam CR, Freeman TR. Medicina Centrada na Pessoa: transformando o método clínico. 3a ed. Porto Alegre: Artmed; 2017.

7. Loeb AE, Rao SS, Ficke JR, Morris CD, Riley 3rd LH, Levin AS. Departmental experience and lessons learned with accelerated introduction of telemedicine during the Covid-19 crisis . J Am Acad Orthop Surg. 2020;28(11):e460-79 [access in 20 jun 2020]. Available from: https:// pubmed.ncbi.nlm.nih.gov/32301818.

8. Universidade Federal do Rio Grande do Sul. Coronavírus (Covid-19): informações para profissionais da APS. Porto Alegre: Faculdade de Medicina; 2020 [access in 7 may 2020]. Available from: https://www.ufrgs. br/telessauders/teleconsultoria/0800-644-6543/\#telecondutas-0800.

9. Freitas BAC, do Prado MRMC, FialhoWL. Telessaúde Covid: teleatendimento e telemonitoramento de pacientes com suspeita ou confirmação de Covid-19. Parceria entre o Departamento de Medicina e Enfermagem da Universidade Federal de Viçosa e a Secretaria Municipal de Saúde de Viçosa-MG. Viçosa; 2020 [access in 2 jun 2020]. Available from: https:// www2.dti.ufv.br/noticias/files/anexos/1591023147.pdf.

10. Minas Gerais. Atualização técnica ao protocolo de infecção humana pelo Sars-Cov-2 n 02/2020 - 23/03/2020. Definições de casos operacionais e fluxos de testagem laboratorial e notificação dos casos. Belo Horizonte: Secretaria de Estado de Saúde, Centro de Operações de Emergência em Saúde; 2020 [access in 3 apr 2020]. Available from: https://www.saude. mg.gov.br/images/noticias_e_eventos/000_2020/24-03-Atualizacao_ Protocolo-02-Casos-Operacionais-e-Fluxos-de-Testagem-LaboratorialNotificacao-dos-Casos.pdf.
11. Minas Gerais. Atualização técnica ao protocolo de infecção humana pelo Sars-Cov-2 n 05/2020 - 19/05/2020. Definições de casos operacionais e fluxos de testagem laboratorial e notificação dos casos. Belo Horizonte: Secretaria de Estado de Saúde, Centro de Operações de Emergência em Saúde; 2020 [access in 28 jun 2020]. Available from: https://www.itauna mg.gov.br/arquivos/19-05-atualizacao-protocolo_20115027.pdf.

12. Minas Gerais. Nota técnica Coes Minas Covid-19 no 8 - 20/03/2020. Orientações sobre ações frente ao enfrentamento da infecção humana pelo Sars-Cov-2 (doença pelo coronavírus - Covid-19) para as equipes do Programa Melhor em Casa - Serviço de Atenção Domiciliar. Belo Horizonte: Secretaria de Estado de Saúde, Centro de Operações de Emergência em Saúde; 2020 [access in 20 apr 2020]. Available from: https://www.saude. mg.gov.br/coronavirus/profissionaisdesaude.

13. Espírito Santo. Nota Técnica Covid-19 no 03/2020. Definições para afastamento laboral para profissionais de serviços essenciais. Vitória: Secretaria da Saúde; 2020 [access in 28 jun 2020]. Available from: https:// saude.es.gov.br/Media/sesa/coronavirus/Notas\%20T\%C3\%A9cnicas/ NOTA\%20T\%C3\%89CNICA\%20COVID.19\%20N.\%2003.20.\%20 Defini\%C3\%A7\%C3\%B5es\%20de\%20Afastamento\%20Laboral.pdf.

14. Centers for Disease Control and Prevention. Coronavirus disease 2019 (Covid-19): interim clinical guidance for management of patients with confirmed coronavirus disease (Covid-19). Georgia: Centers for Disease Control and Prevention; 2020 [access in 28 jun 2020]. Available from: https://www.cdc.gov/coronavirus/2019-ncov/hcp/clinical-guidancemanagement-patients.html.

15. Ohannessian R, Duong TA, Odone A. Global telemedicine implementation and integration within health systems to fight the Covid-19 pandemic: a call to action. JMIR Public Health Surveill. 2020;6:e18810 [access in 20 jun 2020]. Disponíve em: https://publichealth.jmir.org/2020/2/e18810.

16. Gusso G, Lopes J.Tratado de medicina de família e comunidade: princípios, formação e prática. 2a ed. Porto Alegre: Artmed; 2018.

17. Conselho Federal de Medicina. Entra em funcionamento serviço que permite validar receitas médicas e atestados digitais. Brasília; 23 abr. 2020 [access in 30 apr 2020]. Available from: http://portal.cfm.org.br/index. php?option=com_content $\&$ view=article\&id=28674:2020-04-23-13-3834\&catid=3\#: :text=0 Conselho Federal de Medicina,Telemedicina\%2C emitir atestados ou receitas.

18. Brasil. Parecer Técnico n 67/2020-CGPNI/DEIDT/SVS/MS: indicação, em caráter excepcional, do uso do fosfato de Oseltamivir durante a pandemia da Covid-19. Brasília: Ministério da Saúde, Secretaria de Vigilância em Saúde, Departamento de Imunização e Doenças Transmissíveis, Coordenação-Geral do Programa Nacional de Imunizações; 2020 [access in 18 may 2020]. Available from: https://www.cosemssc.org.br/parecertecnico-no-67-2020-cgpni-deidt-svs-ms/.

19. Grupo Força Colaborativa Covid-19 Brasil. Orientações sobre diagnóstico, tratamento e isolamento de pacientes com Covid-19. 2020 [access in 3 may 2020]. Available from: https://www.infectologia.org.br/ad$\mathrm{min} /$ zcloud/125/2020/04/58d801e961f64463109881311316e4e661d8a1e865fb7638ad61c0827cd83430.pdf.

20. TelessaúdeRS-UFRGS. Orientações para os casos com indicação de isolamento domiciliar. 2020 [access in 15 may 2020]. Available from: https://www.ufrgs.br/telessauders/documentos/telecondutas/material_ isolamento_corona_virus_20200303_ipn_002.pdf.

21. Cole SA, Bird J. The medical interview: the three function approach. $3 \mathrm{rd}$ ed. Philadelphia: Elsevier; 2014.

22. OmboniS.Telemedicine during the Covid-19 in Italy: a missed opportunity? Telemed J E Health. 2020;26(8):973-5. doi: 10.1089/tmj.2020.0106.

23. Dorsey ER, Topol EJ. Telemedicine 2020 and the next decade. Lancet 2020;395(10227):859 [access in 2 jun 2020]. Available from: https:// www.thelancet.com/journals/lancet/article/PIIS0140-6736(20)30424-4/ fulltext\#.Xtaypz3TtgU.mendeley. 